\title{
Spermatotoxic effects of selected traditional alcoholic beverages from North-Central Nigeria on adult male albino rats
}

\section{Olusayo Moritiwon 1, Timothy Olugbenga Ogundeko 2, ${ }^{*}$, David Oyebode ${ }^{3}$, James Bitrus ${ }^{4}$, Adikpe Emmanuel} Edugbe ${ }^{4}$, Mamzhil Seljul Crown Ramyil ${ }^{5}$ and Amos Paul Bassi 6

${ }^{1}$ Department of Pharmacology and Toxicology, Faculty of Pharmaceutical Science, University of Jos, Nigeria.

2 Department of Pharmacology and Therapeutics, College of Medicine and Health Sciences, Bingham University, Jos Campus Nigeria.

${ }^{3}$ Department of Hematology, Federal School of Medical Laboratory Science, Jos University Teaching Hospital, Nigeria.

4 Department of Obstetrics and Gynecology, College of Medicine and Health Sciences, Bingham University, Jos Campus Nigeria.

${ }^{5}$ Department of Microbiology and Parasitology, College of Medicine and Health Sciences, Bingham University, Jos Campus Nigeria.

${ }^{6}$ Department of Community Medicine and Public Health, College of Medicine and Health Sciences, Bingham University, Jos Campus Nigeria

Magna Scientia Advanced Biology and Pharmacy, 2021, 02(02), 014-022

Publication history: Received on 09 April 2021; revised on 17 May 2021; accepted on 20 May 2021

Article DOI: https://doi.org/10.30574/msabp.2021.2.2.0023

\begin{abstract}
Challenges associated with habitual intake of alcohol including health, social, psychological and especially reproductive health needs urgent attention. This study aimed to determine the spermatotoxic effect of selected traditional alcoholic beverages in rats. A total of 30 normal male Spaque dawley strain albino rats weighing 180-220g, divided into 5 groups of 6 rats in each were administered with $10 \mathrm{ml} / \mathrm{kg}$ p.o each of pito, goskolo and ogogoro, goskolo respectively and $0.5 \mathrm{ml} / \mathrm{kg}$ normal saline for a period of 21 days.
\end{abstract}

Sperm samples were harvested from the left caudal portion epididymis assayed for sperm motility, sperm morphology and sperm count after which histological examination was carried out on the testes. Results showed that active, sluggish and dead sperm cells were goskolo>pito>burukutu>control>ogogoro, ogogoro $>$ burukutu> control>goskolo $>$ pito and control>pito>ogogoro>burukutu>goskolo respectively. For morphology of sperm cells, it was goskolo>ogogoro $>$ burukutu>control>pito (normal) and pito>control>burukutu> ogogoro $>$ goskolo (abnormal). Also, that of sperm count was goskolo>ogogoro>pito>burukutu>control.

Results further showed that ogogoro and goskolo caused significant negative effects on quantity and quality of sperm cells with alteration of histological parameters marked with altered secondary spermatogonia and spermatid. These effects were however mild with pito and burukutu.

Traditional alcoholic beverages from North central Nigeria 'pito', 'burukutu', 'ogogoro', and goskolo' have negative on the quantity and quality of sperm cells with marked with infraction of spermatogonia of male albino rats. As a result of the spermatotoxic properties of these locally available and often ingested drinks by males predominantly in the reproductive age brackets will do well to avoid and or minimize its use as it leads to reprotoxicity.

Keywords: Sperm motility; Sperm morphology; Sperm count; Testicular section; Traditional alcoholic beverages; Reprotoxicity

\footnotetext{
${ }^{*}$ Corresponding author: Timothy Olugbenga Ogundeko

Department of Pharmacology and Therapeutics, College of Medicine and Health Sciences, Bingham University, Jos Campus Nigeria. 


\section{Introduction}

Challenges associated with habitual intake of alcohol including health, social, psychological and especially reproductive health needs urgent attention. Africans live communal lives and as such drinking of traditional alcoholic beverages is part of their socialization and such a social habit.

The WHO (2018) [1] attributed an approximately 3.3 million deaths every year (or 5.9\%) of all death and 5.1\% of the global burden of disease to alcohol consumption. The unrecorded alcohol consumption such as the local brews: burukutu, pito, goskolo and ogorogo in Nigeria is said to have been estimated at 3.5 liters pure alcohol per capita for population of people older than 15 for the year after 1995 [2]. Studies have shown that for both men and women there is a sharp upward tick in alcohol consumption during adolescence, that peaks in early adulthood and plateaus at midlife and declines as they get into older ages [3]. It was also found out that $69.1 \%$ of alcohol users in certain regions of Nigeria have either moderate or high health risks from the consumption of alcohol [4]. It is also clear that the fertility, reproductive stature age range fall within 15-49 years of age and it peaks within the 20-34 years in different urban settlements for women, with a little difference in rural areas where there is low education and other factors that make people marry at early age [5]. Studies have shown fertility increase within 30-40 years for men [6].

The effect of traditional alcoholic beverages revealed the classical effects of alcoholic drinks by way of significant alteration in the estrous cycle of albino rats with marked alteration of the histological architecture of ovarian tissues. Pito, goskolo and ogorogo and goskolo have a reprotoxic effect on the ovaries and uterus thus a deleterious effect on fertility of female albino rats [7]. Also, 'pito', 'burukutu', 'ogogoro', and 'goskolo' has revealed the have classical effects of alcoholic drinks in that, they were able to cause sexual disinhibition in male rats and suppression of sexual motivation in female rats [8]. The toxicological evaluation of traditional alcoholic beverages pito, goskolo and ogorogo go and goskolo revealed significant decrease in the sex hormonal profile of male and female albino rats. This buttressed the toxicological effect by way of decrease in the activity of the sex hormones necessary for fertility and reproduction the rats [9].

The treatment and management of infertility has become a global pressing concern as the need to have children is of great priority in families especially in Africa [10]. It was reported that about $15 \%$ of couples of reproductive the age are infertile and about $50 \%$ of these cases are male related [11]. Alcohol toxicity produce a significant deterioration on sperm concentration output and motility thus resulting in increased damage of spermatozoa [12, 13]. Although male infertility due to endocrine disorders reportedly accounts for below 3\% of infertility cases in males [14], hormone assay for males is done to both identify causative factors for endocrine abnormalities and to obtain prognostic information. Agents that interfere with reproduction may do so by affecting spermatogenesis at the testicular level or changing the body's hormone profile or both.

Global rise in infertility cases amongst male, has been attributed to decline in semen quality [15]. Male infertility among Nigerians has also been reported to be responsible for about 20-50\% of all infertility cases in different parts of the country [16]. Understanding the prevalence and nature of male infertility across Africa has been quite difficult because of insufficient data and the fact that African males rarely agree to undergo fertility tests and usually prefer to blame the females for nearly all cases of infertility in the family [17]. A number of factors that contribute to male infertility includes poor semen quality [18], including hypothalamic pituitary disease, testicular disease, disorders of sperm transport and idiopathic male disease [19]. Other known causes are exposure of the testicles to abnormally high temperatures, developmental history such as cryptorchidism, erectile dysfunctions, diseases such as diabetes and respiratory infections, and past surgical and cancer treatments. Other contributors are lifestyle factors such as exposure to environmental toxins like cadmium, mercury, arsenic compounds, hydrocarbons, alcohol, cigarette smoking and pesticides [20] could be attributed to the causes of low sperm count, inadequate sperm motility, abnormal morphological structures or a combination of these factors [21].

\section{Material and methods}

\subsection{Procurement of experimental animal and protocol}

A total of 30 normal male albino rats (Spaque dawley strain) weighing 180-220g of about 12 weeks were purchased from the Animal House of the University of Jos, Nigeria. The animals were randomly divided five groups (I - V) of six animals per cage, acclimatized for 72 hours prior to commencement of experiment, fed with grower mash (Vital Feed Nigeria) and allowed access to water ad libitum. This was done as reported by Moritiwon et al., 2021 [8, 9]. 


\subsubsection{Procurement, preparation of alcoholic beverages and administration protocol}

The following types of freshly prepared locally brewed alcoholic beverages - goskolo, burukutu, pito and ogogoro were purchased daily from the same commercial brewer in Angwan Rukuba (a settlement in Jos North LGA, North Central Nigeria) for the period of experiment in order to eliminate the errors of fermentation. Following the 72 hours of acclimatization, the animals were administered with various doses of the local alcoholic beverages orally via a canula for a period of 21 days prior to the assays according to the methods of [9,22], using the following schedule:

Group I received $10 \mathrm{ml} / \mathrm{kg}$ of pito, Group II received $10 \mathrm{ml} / \mathrm{kg}$ of burukutu, Group III received $10 \mathrm{ml} / \mathrm{kg}$ of ogogoro, and Group IV received $10 \mathrm{~m} / \mathrm{kg}$ of goskolo, while Group V received $0.5 \mathrm{ml} / \mathrm{kg}$ normal saline.

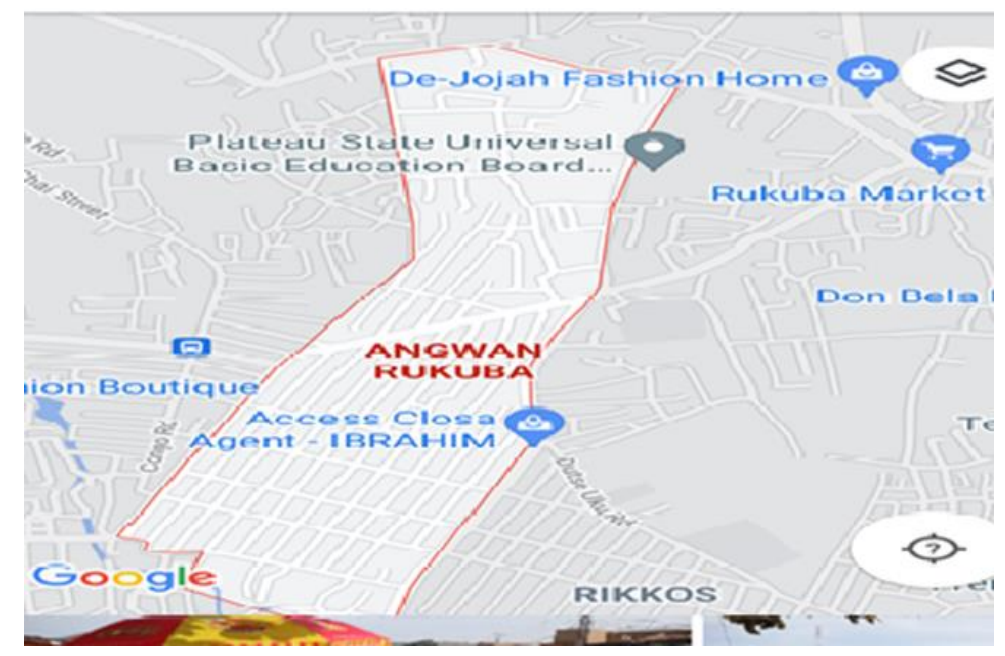

Figure 1 Google map of Angwan Rukuba, Jos Plateau State, Nigeria [23]

\subsection{Sperm samples collection and assays}

Following various treatments, each rat was euthanized by cervical dislocation and sperm samples were harvested from the left caudal portion epididymis in pre-warmed phosphate-buffered saline at $37^{\circ} \mathrm{C}$ and $\mathrm{pH}=7.4$ ). The tissue was gently agitated for about 25 minutes to aid smooth dispersion of the sperm cells. The various sperm assays were however carried out as described by El-Sherbiny (1987) [24], Chibundu (2013) [25] and Ukar et al., (2016) [26]. The values were presented in percentages.

\subsubsection{Sperm motility assay}

The sperm samples collected via epididymal washings from each treatment group (I - V) and evaluated for progressive motile sperm cells immediately after collection. A smear of one drop of the sperm sample was made on a pre-heated glass slide and viewed under light microscopy at X10 and X400 magnifications and subjectively scored in percentage. The following motility scale was also used to score individual sperm motility: 1 (vigorously progressive), 2 (progressive), 3 (cycling movement) and 4 (stationary movement).

\section{Inclusion criteria}

These were sperm cells that moved in straight and forward direction.

\section{Exclusion criteria}

These included sperm cells moving in backward and circler direction and such that showed pendular movement.

\subsubsection{Sperm count and morphology assays}

Sperm count was determined by dilution of $1 \mathrm{~mL}$ of the sperm suspension with $1 \mathrm{~mL}$ of $10 \%$ Formaldehyde (FA) fixative. $10 \mathrm{~mL}$ of mixture was transferred into a hemocytometer and sperm count was evaluated per 250 small squares of a hemocytometer. The morphology in terms of percentage normality and abnormality of the sperm cells were considered and recorded appropriately. 


\subsection{Histological assay}

Following the assays on the sperm, the rats were sacrificed and the testis were harvested, weighed, fixed in Bouin's fluid for 12 hours and processed, sectioned, stained and mounted according to the methods of Cito et al., (2018) [27], Suvarna et al., (2012) [28] and Ngadjui et al., (2013) [29]. The mounted tissues were observed under the X400 objective of the microscope.

\subsection{Statistical analysis}

Statistical Package for Social Sciences (SPSS) version 20 was used in analysis of experimental data. While comparisons were done by analysis of variance (ANOVA) and student t-test. The level of significance chosen was $\mathrm{p}<0.05$. The data obtained from all groups were presented percentages, mean $\underline{\underline{ }} \mathrm{SEM}$ and charts.

\section{Results and discussion}

For the sperm motility in terms of percentage active sperm cells, the highest percentage active sperm cell was observed in the shown by the ogogoro administered group (72\%) when compared with Control $(66.40 \%)$ while the least active was that of goskolo (42.4\%). There was significant difference for the group that were administered with goskolo 0.005 $(p<0.05)$ thus having the lowest percentage of active sperm cells $(42.4 \%)$. However, it was different for the other alcoholic drinks - ogogoro, burukutu and pito where there was no significant difference when compared with control. The percentage active sperm cells was higher in the ogogoro group, though not significantly. The order of increase percentage active sperm cell was Goskolo>Pito $>$ Burukutu>Control>Ogogoro [Figure 2].

The percentage sluggish sperm cells were $37.4 \%, 33.6 \%, 20 \%$ and $18 \%$ for pito, goskolo, burukutu and ogogoro respectively compared with the control group (29.6\%), leaving the order of increasing sluggish sperm cells as ogogoro>burukutu>control>goskolo>pito. This showed no significant difference in all the groups of alcoholic drinks studied [Figure 2].

As for the percentage of dead sperm cells, the group treated with goskolo was $24 \%$ compared with Control (4\%) while other groups were pito (8\%), ogogoro (12\%) and burukutu (16\%). There was significant difference in the group fed with goskolo 0.006 , burukutu 0.005 and ogogoro 0.010 in each case compared with the control group $(p<0.05)$ except that of the Pito group. The order of increasing dead sperm cell was control>pito>ogogoro $>$ burukutu>goskolo. One could deduce that goskolo reduced the active sperms and caused more sperm cells die [Figure 2].

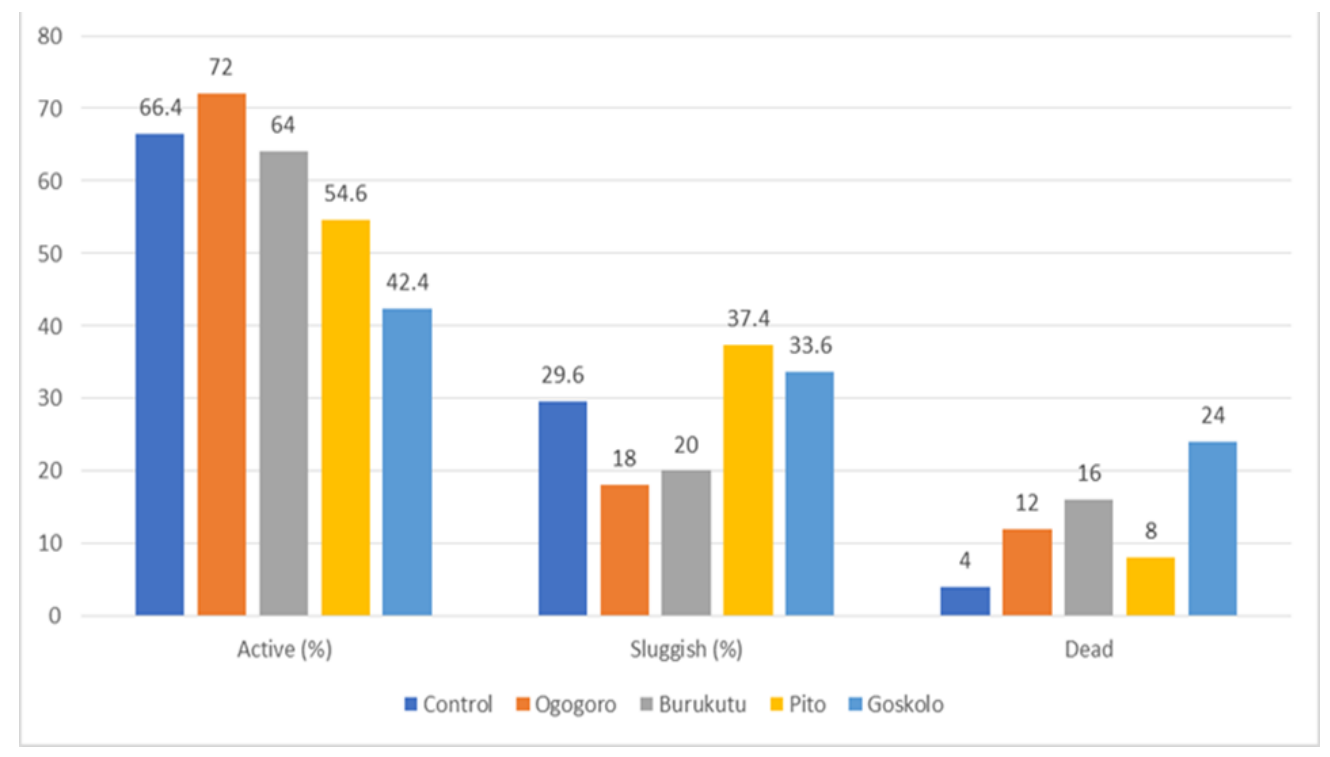

Figure 2 Effect of some traditional alcohol beverages on the sperm motility (\%) of albino rats

In terms of the morphology (percentage normal and abnormal sperm cells), the albino rats that were treated with Pito (83\%; 17\%) compared with the Control (77.60\%;22.4\%). Both Burukutu and Ogogoro (74\%; 26\%) and Goskolo (66\%; $34 \%)$. The result further showed that there was no significant difference between the group fed with Ogogoro, Burukutu, Pito and Goskolo $(p \geq 0.05)$. The alcoholic drinks under this study did not significantly change the structure or morphology of the sperm cells. Similarly, when the test groups were compared with the Control with respect to the 
percentage of abnormal sperm cells morphology, all the test groups of Ogogoro, Burukutu, Pito and Goskolo ( $p<0.05$ ) were not significantly marred. The order of increasing normality of sperm cell from this table was Goskolo>0gogoro $>$ Burukutu>Control>Pito while the increase abnormality was Pito >Control $>$ Burukutu> Ogogoro $>$ Goskolo [Figure 3].

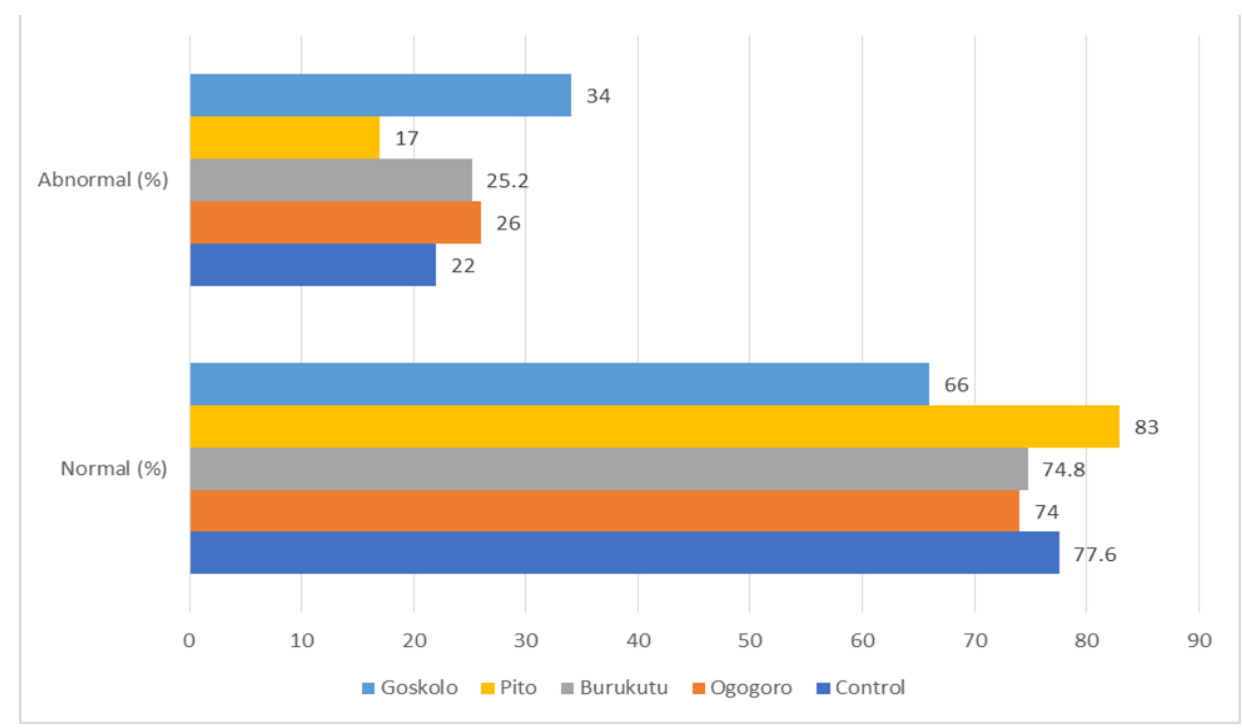

Figure 3 Effect of Some Traditional Alcohol Beverages on the Sperm (\%) Morphology of Albino Rats

Regarding sperm count, it was observed that there was reduction in the sperm count of the rats. Percentage sperm count in the treated groups compared with the control group were - Burukutu (60.80\%), Pito (52\%), Ogogoro (49\%), Goskolo (41\%) and $77.5 \%$ for Control respectively. The effect of these alcoholic beverages was not statistically significant for all the drinks except Goskolo 0.011 ( $p>0.05)$ when compared with control rats. The order of increasing sperm count was Goskolo $>$ ogogoro $>$ Pito $>$ Burukutu $>$ Control [Figure 4].

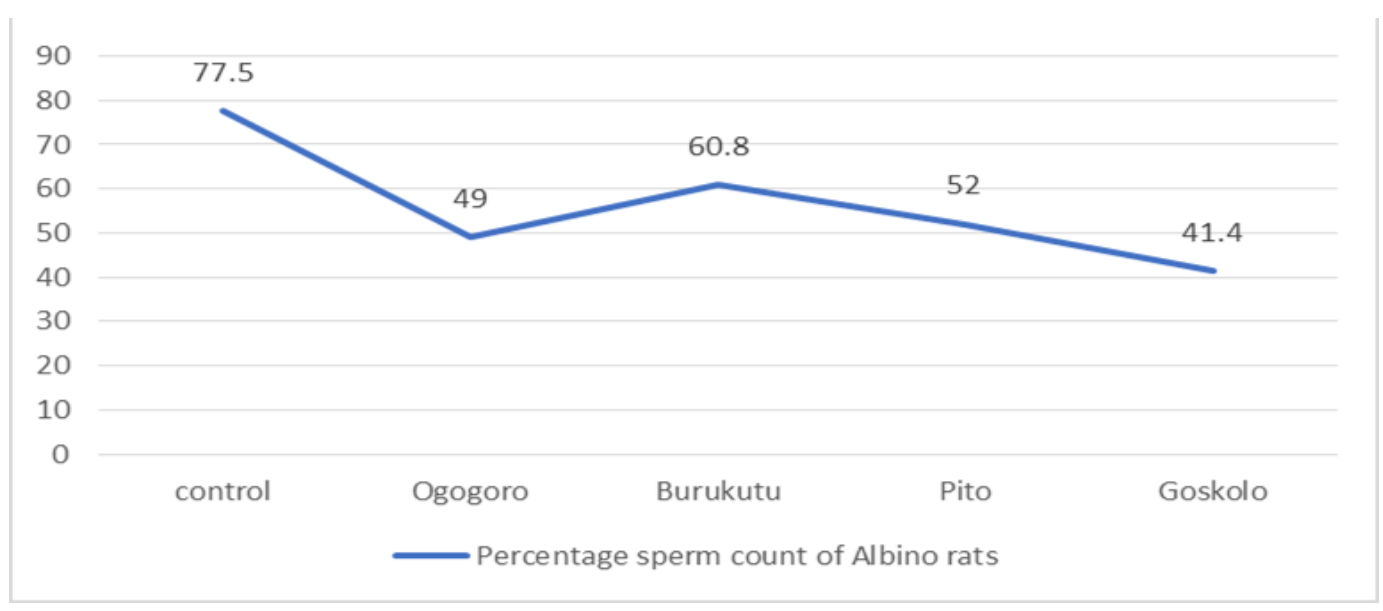

Figure 4 Effect of Some Traditional Alcohol Beverages on Sperm Count (\%) of Albino Rats

Findings on the motility of sperm cells suggest a trend that alcohol ingestion have a negative effect on the motility and activeness of sperm cells though, in a moderate manner. The trend is indicative of reduction in the quantity of active sperm cells, increased sluggish sperm cells and significant amount of dead sperm cells, which agreed with the suggestion of Alverez and Struss (1995) [30], that ethanol increases in plasma membrane of spermatozoa which are ready substrate for the free radicals production leading oxidative stress in the testis, explains the gradual reduction in activeness of sperm cells found in the groups that indigested different samples of ethanol found in Pito, goskolo and ogorogo and Goskolo. Mitochondria produces ATP required for movement of flagella of sperm cells, if there is a reduction or impairment in mitochondrial function which was what was reported by Coleman and Cummingham, (1990) [31], for the liver function. This suggests that there are possibilities that the mitochondria of the testicular cells may be affected too, resulting in non- motile, sluggish and dead sperm cell. This ultimately suggest some levels of infertility among the male [32]. On the other hand, Ogogoro displayed an unusual of increase in activity of sperm cell beyond the control rats 
implying that there could be presence of substances in Ogogoro that resulted in an increase in the sperm cells activeness. This suggests the need further research on same.

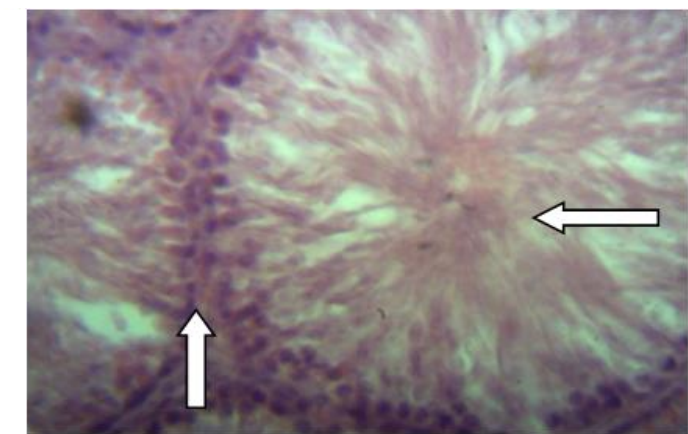

X400

Plate (1): Photomicrograph of a testicular section of male rat treated with $0.5 \mathrm{ml}$ normal saline showing massive sperm cells

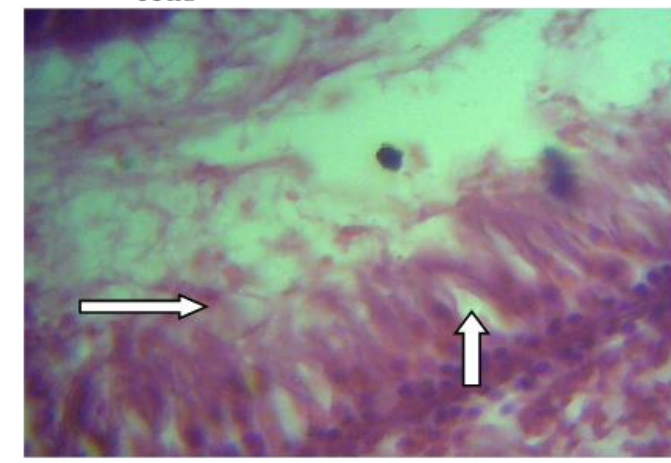

$\mathrm{X} 400$

Plate (3): Photomicrograph of a testicular section of male rat treated with $10 \mathrm{ml} / \mathrm{kg}$ of Burukutu showing altered testicular structures

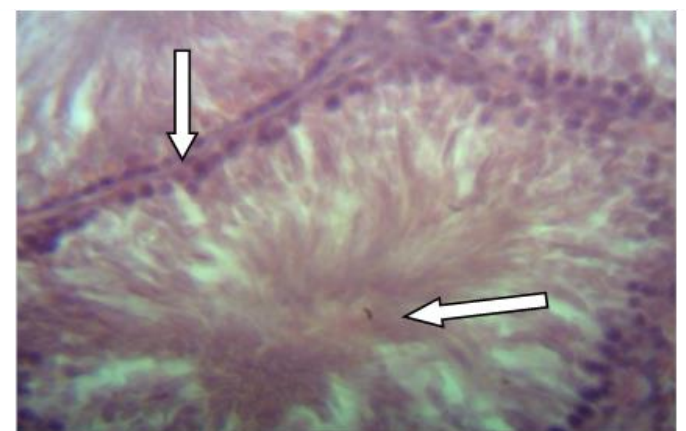

$\mathrm{X} 400$

Plate (2): Photomicrograph of a testicular section of male rat treated with $10 \mathrm{ml} / \mathrm{kg}$ of Pito showing massive sperm cells

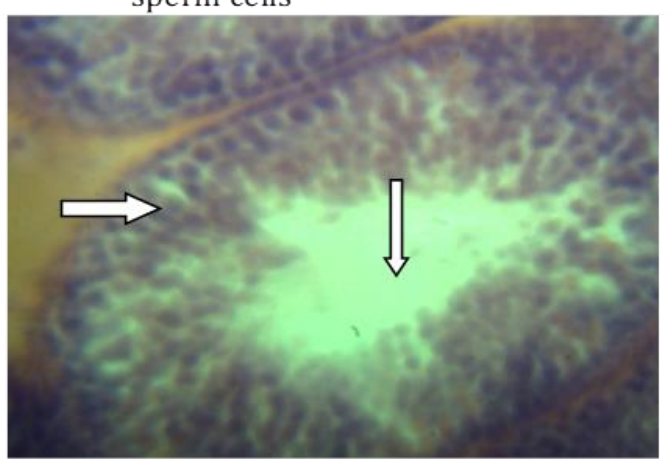

$\mathrm{X} 400$

Plate (4): Photomicrograph of a testicular section of male rat treated with $10 \mathrm{ml} / \mathrm{kg}$ of Ogogoro showing altered testicular structures

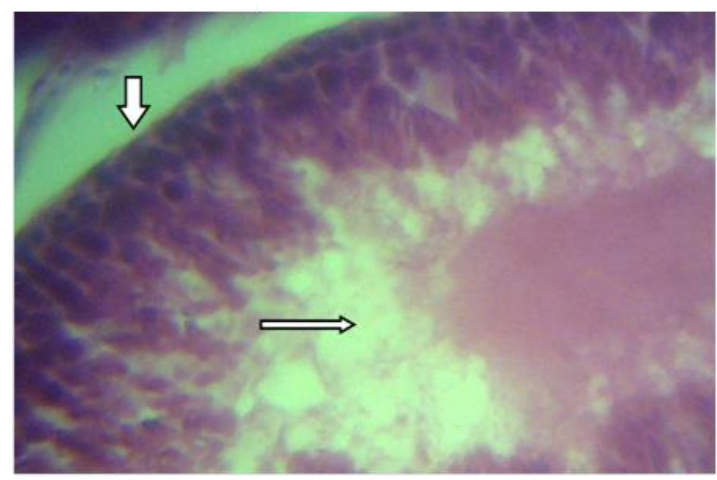

X 400

Plate (5): Photomicrograph of a testicular section of male rat treated with $10 \mathrm{ml} / \mathrm{kg}$ of Goskolo showing altered testicular structures

Figure 5 Photomicrographs of testicular sections of experimental animals

From the histology of the testis, it was evident that burukutu, ogogoro and goskolo exerted reprotoxic effects - plates 3, 4 and 5. Burukutu caused the formation of clustered sperm cells with no clear distinction of each cell. There was enlargement of spermatids and all spermatogenic cells were clearly altered - plate 3. Ogogoro intake also resulted gross disruption of the testicular architecture with spermatogenic cells hypertrophy and its lumen was empty of matured sperm cells (plate 4) while goskolo also caused spermatogenic cells hypertrophy which may be possibly as a result of infarctions, then the lumen was filled with cluster of deformed sperms cells - plate 5. These also may have possibly resulted from the effect of the oxidant that the metabolism of alcohol produces [33, 34]. These results are in line with 
studies that suggested that alcohol caused histological abnormalities in testicular tissue of animals such as sloughing and shortening of semiferous, atrophy of semiferous tubules leading to a reduction of seminiferous testicular diameter and cross-sectioned [35, 36, 37].

On the other hand, histological assay of the testis of rats fed with Pito did not show oblivious pathological changes (plate 2). This contradict the study of Dosumu et al., (2014) [37] which suggested that alcohol induced damage on the testis.

\section{Conclusion}

Traditional alcoholic beverages from North central Nigeria 'pito', 'Burukutu', 'Ogogoro', and Goskolo' have negative on the quantity and quality of sperm cells with marked with infraction of spermatogonia of male albino rats. As a result of the spermatotoxic property, males in the reproductive age should abstain from habitual intake of 'pito', 'Burukutu', 'Ogogoro', and Goskolo' in order to guide against reprotoxicity.

\section{Compliance with ethical standards}

\section{Acknowledgments}

Authors appreciate the guidance by Professors NN Wannang and JI Ogaji and the support from the brewers of the traditional alcoholic beverages in Angwan Rukuba, Jos North LGA, Plateau state, Nigeria.

\section{Disclosure of conflict of interest}

All the authors - Olusayo Moritiwon, Timothy Olugbenga Ogundeko, David Oyebode, James Bitrus, Adikpe Emmanuel Edugbe, Mamzhil Seljul Crown Ramyil and Amos Paul Bassi hereby disclose no conflict of interest.

\section{Statement of ethical approval}

Authors TOO and MSCC are licensed to handle laboratory animals in conformation with ethical standards.

\section{Statement of informed consent}

The present research work does not require statement of informed consent.

\section{References}

[1] Global status report on alcohol and health 2018. World Health Organization. [cited 2021, Jan 2]. Available from: https://www.who.int > Publications.

[2] World Health Organization. International programme on chemical safety. Principle of for evaluating health risk to reproduction associated with exposure to chemicals environmental health criteria. Geneva: WHO Press. 2001; 225.

[3] Geggel L. Alcohol intake peaks at age 25 but Continuous into old Age. Live Science.com 2015, March, 9. [cited 2020, Dec 31] Available from: https://ca.news.yahoo.com

[4] Lasebikan VO, Ola BA. Prevalence and Correlates of Alcohol Use among Sample of Nigeria Semirural Community Dwellers in Nigeria. Journal of Addition. 2016; 6.

[5] Fotso JC, Ajayi JO, Idoko EE, Speizer I, Fasiku DA, Mberu B, Mutua M. 2011. [Internet]. Family Planning and Reproductive Health in Urban Nigeria: Levels, Trends and Differentials. Chapel Hill, NC: Measurement, Learning \& Evaluation (MLE) Project [UNC, USA] and National Population Commission (NPC) [Nigeria]. [cited 2021 May 22]. 44 p. Cat No: 2 - 2010 PER 35. Available from: www.urbanreproductivehealth.org

[6] Harris ID, Fronezale C, Roth L, Muschan R. Fertility and the Aging Male. Review in Urology. 2011; 13(4): e184e190.

[7] Moritiwon O, Ogundeko TO, Bitrus J, Oyebode D and Abobarin OI. Effect of some Nigerian traditional alcoholic beverages on the estrous cycle and histological assessment of the ovaries and uterus of albino rats. GSC Biol. and Pharm. Sci. 2021; 14(01): 027-036.

[8] Moritiwon O, Wannang NN, Ogundeko TO, Ogaji JI. Effect of some Traditional Alcoholic Beverages on Sexual Behavior of Albino Rats." IOSR J. of Pharm. (IOSRPHR). 2021; 11(01): 12-18. 
[9] Moritiwon O, Ogundeko TO, Oyebode D, Bitrus J, Bassi AP. Evaluation of selected locally brewed alcoholic beverages on the serum hormonal profile of albino rats. World J. of Adv. Research and Reviews. 2021; 09(01): 037045 .

[10] Shukla K, Mahdi AA, Ahmad MK, Jaiswar MP, Shankwar SC. Tiwari Mucuna pruriens reduces stress and improves the quality of semen in infertile men. Evidence-Based Complementary and Alternative Medicine. 2010; 7: 137-144.

[11] McLachlan R, Krester D. Male infertility: The case for continued research. The Med. J. Australia. 2001; 174: 116117.

[12] Kucheria K, Saxena R, Mohan D. Semen analysis in alcohol dependent Syndrome. Andrologia. 1985; 17: 558-563.

[13] Brzek A. Alcohol and male fertility (Preliminary report). Andrologia. 1987; 19: 32-36.

[14] Hideyuki K, Koichi N, Koichi N. Focus issue on male infertility. Adv Urol. 2012; 1-6.

[15] Abarikwu SO. Causes and risk factors for male-factor infertility in Nigeria: A review. Afr J Reprod Health. 2013; 1: 150-166.

[16] Eze KN. Anti-fertility effects of ethanolic extract of Xylopia aethiopica on male reproductive organ of wistar rats. Americ. J Med Oxyopia Sci. 2012; 2: 12-15.

[17] Agarwal A, Mulgund A, Hamada A. Chyatte A unique view on male infertility around the globe. Reprod Bio Endo. 2015; 13: 37-46.

[18] Willott GM. Frequency of azoospermia. Forensic Sci Int. 1982; 20: 9-10.

[19] Kandeel FR, Koussa VK, Swerdloff RS. Male sexual function and its disorders: Physiology: Pathophysiology, Clinical Investigation and treatment. Endocrinology Revised. 2001; 22: 342.

[20] Kumar N, Singh AK. Trends of male factor infertility, an important cause of infertility: A review of literature. J Hum Reprod Sci. 2015; 8: 191-196.

[21] Oyedeji KO, Bolarinwa AF, Afolabi OA. Effect of tetracycline on heamatological and reproductive parameter in female albino rats. Asian J. of pharm and clinical research. 2013; 3: 230-232.

[22] Wannang NN, Gyang SS, Banwat SB, Goncin HY, Mador ES, Oni IA. Effect of Locally Consumed Alcoholic Beverages ('Burukutu', 'Pito', and 'Goskolo') on the weight of and Anatomy of Testicular Tissues. African J. of Pharm. Research and Dev. 2011; 3(1): 57-60.

[23] Google Maps, 2021. ARU: Angwan Rukuba, Jos North, Plateau State, Nigeria 1:1.500. Google Maps [online] Available through: https://www.mindat.org > feature-9113212 [Accessed 28 April 2021].

[24] El-Sherbiny AM. Seasonal variation in seminal characteristics of rabbits. M.Sc. Dissertation. Fac. of Agric, AinShams University.1987.

[25] Chibundu UC. Response of pre-pubertal bucks to administration of estradiol B" Project. Federal University of Technology Owerri: Nigeria. 2013; 30.

[26] Ukar AI, Herbert U, Umeze EM. Proceedings of the 42nd Annual Conference of Nigerian Society of Animal Production; Kwara State. 2016; 853-859.

[27] Cito G, Coccia ME, Picone R, Nesi G, Cocci A, Dabizzi S, Garaffa G, Fucci R, Falcone P, Bertocci F, Santi R, Criscuoli L, Serni S, Carini M, Natali A. Novel method of histopathological analysis after testicular sperm extraction in patients with nonobstructive and obstructive azoospermia. Clin Exp Reprod Med. 2018 Dec; 45(4): 170-176.

[28] Suvarna SK, Layton C, Bancroft JD. Practice of histological techniques: pharmacology [Internet]. 8th ed., Elsevier Ltd; 2019. Chapter 9, Theory of histological Staining; [cited 2021 Jan 3]. p. 114-25. Available from: www.elsevier.com. www.bookaid.org

[29] Ngadjui E, Watcho P, Nguelefack TB, Kamanyi A. Effects of Ficus asperifolia on normal rat estrus cyclicity. Asian Pac. J. Trop Biomed. 2013; 3: 53-57.

[30] Alvare JG, Storey BT. Differential incorporation of fatty acids into and peroxidative loss of fatty acids from phospholipids of human spermatozoa. Molecular Reproductive Development. 1995; 42: 334-346.

[31] Cunningham CC, Coleman WB, Spach PI. The effects of chronic ethanol consumption on hepatic mitochondrial energy metabolism. Alcohol Space. 1990; 25: 127-136. 
[32] Viegnera LS, Condorelli RA, Balercia G, Vicari E, Calogero AE. Does Alcohol have any effect on male reproductive function? A review of literature. Asian J. of Andrology. 2013; 15(2): 221-225.

[33] Emmanuel A, Emmanuel N. Alcohol and Male reproductive system. National Institute on Alcohol abuse and Alcholism. Alcohol Health Research World. 1998; 22(3): 195-201.

[34] Adams ML, Nock B, Truone R, Cicero TJ. Nitric oxide control of steroidogenesis Endocrine effect of N-Nitro-LSigine and comparison to alcohol. Life science. 1992; 50: 35-40.

[35] Martinez M, Macera S, Assis GF, Pinheiro PF, Almeida CC, Tirapelli LF, Martinez FE. Structural evaluation of the effects of chronic ethanol ingestion on the testis of Calomys callosus Tissue Cell. Science Direct. 2009; 41: 199205.

[36] Adaramoye OA, Arisekola M. Kolaviron, a biflavonoid complex from Garcinia kola seeds, ameliorates ethanolinduced reproductive toxicity in male Wistar rats. Niger J. of Physiol. Sci. 2013; 28 (1): 9-15.

[37] Dosumu 00, Osinubi AAA, Duru FIO. Alcohol induced testicular damage: Can abstinence equal recovery? Middle East Fertility Society. 2014; 19: 221-228. 